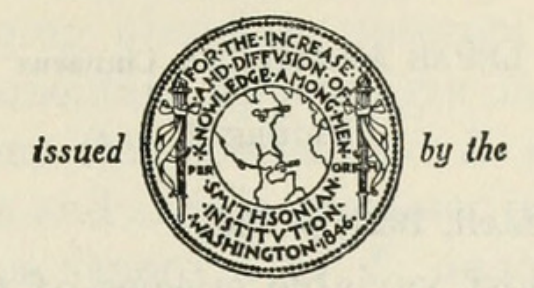

SMITHSONIAN INSTITUTION

U.S. NATIONAL MUSEUM

\title{
NOTES ON SOME PEDUNCULATE BARNACLES FROM THE NORTH PACIFIC
}

\section{By Dora Priaulx Henry}

UNTIL recently it was generally assumed that the species of barnacles of the genus Lepas were easy to identify, but Nilsson-Cantell (1921, 1928), Hiro (1937), and several others have shown that some, at least, are extremely variable. Until some worker is able to examine and compare specimens of the different species from all over the world, some progress may be made in overcoming the difficulties encountered in identifying the species of this genus if descriptions and figures of the specimens of different regions are published.

The barnacles to be described in this paper include an atypical form of Lepas anatifera, a new subspecies of $L$. pectinata, $L$. fascicularis aurivillii, Scalpellum columbianum, and Mitella polymerus. The specimens of Lepas and Scalpellum were collected from several localities between Alaska and Oregon. I am indebted to Prof. Trevor Kincaid, Department of Zoology, University of Washington, and to the College of Fisheries, University of Washington, for allowing me to examine specimens in their collections. Mitella polymerus was collected from Puget Sound, Wash., Oregon, California, and Lower California. Pedunculate barnacles from the North Pacific have previously been reported by Pilsbry (1907) and Broch (1922). 


\section{Genus LEPAS Linnaeus}

\section{LEPAS ANATIFERA Linnaeus}

Figure 1

Synonymy: See Nilsson-Cantell, 1921, p. 236.

This is one of the most variable species of the genus Lepas. The number of filamentary appendages, i. e., one at the bases of the first cirri and one on the prosoma on each side, is the most reliable criterion in differentiating this species from the closely related species, L. hillii. Darwin states that the presence of a tooth beneath the umbo, on the right-hand scutum, and its entire absence on the left constitute an unfailing diagnostic mark. Weltner (1900) found otherwise typical
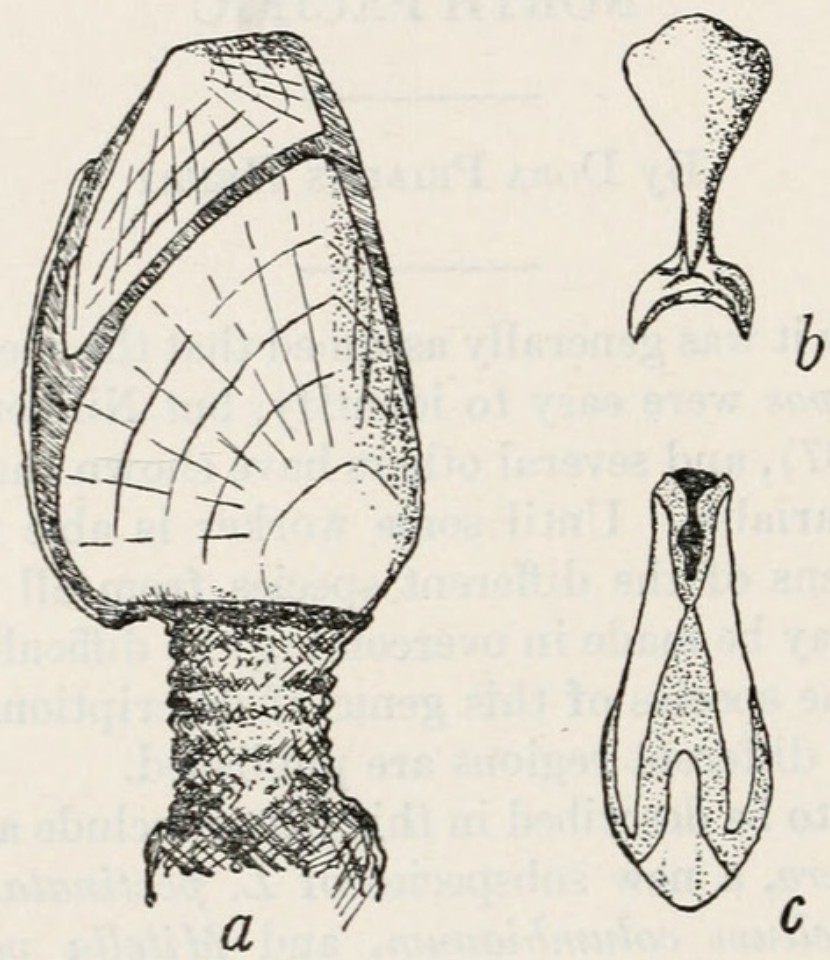

Figure 1.-Lepas anatifera from Harriet Harbor, British Columbia: $a$, Side view, $\times 2$; $b$, carina, external view, $\times 3$; , apex of capitulum from above, $\times 3$.

L. anatifera with an internal tooth on the left-hand scutum as well. Nilsson-Cantell (1928) examined specimens that Cornwall (1925) identified as L. hillii from British Columbia and found an internal umbonal tooth on both scuta. In 1931 this author also described an atypical form, the scuta of which have no umbonal teeth. The absence of umbonal teeth is also one of the diagnostic characters of several varieties; subspecies indica Annandale (1909) has an internal umbonal tooth on the left-hand scutum only. Therefore it can be seen that this character is an extremely variable one.

Miranda y Rivera (1921) proposed a new species, L. marocannus, with the following characters: Plates smooth; carina slightly curved 
and separated from the other plates by a wide membrane; fork with two long and diverging branches; internal umbonal tooth on each scutum; and two filamentary appendages on each side. As the only real difference between this species and $L$. anatifera is the presence of teeth on both scuta and as this character is variable, L. marocannus must be considered a synonym of $L$. anatifera, and until a more comprehensive study is made of this species it does not seem advisable to call it a variety.

The specimens described below were obtained from six localities between Willapa Harbor, Wash., and the Aleutian Islands, and all have an internal umbonal tooth on both scuta.

Description.-The scutum is radially striate. The ridge from the umbo to the apex is never very prominent and in some can scarcely be seen. The occludent margin is nearly straight. The internal tooth of the right scutum is usually larger than that of the left. The internal basal rim does not quite reach the carinal border. The carina is separated by a rather wide interspace from the other valves; the apex is rounded; the greatest width is at the middle, and the narrowest part is just above the fork. The fork is narrower than the widest part of the carina; the rim between the prongs is reflexed. A thick membrane borders the occludent margins of the scuta and terga. The two occludent margins of the terga are nearly at right angles to each other.

The peduncle varies in length in proportion to the length of the capitulum. In young specimens tiny spines occur on the surface as described by Darwin for the young of $L$. austratis. In older specimens no spines were found, but there are irregular chitinous plates scattered over the peduncle. There are two filamentary appendages on each side. The mouth parts and cirri do not differ from those of typical Lepas anatifera. The caudal appendages are small and rounded at the apex.

Size.-In the largest specimen the capitulum is $43 \mathrm{~mm}$. in length and $28 \mathrm{~mm}$. in width, and the peduncle is $50 \mathrm{~mm}$. in length and $13 \mathrm{~mm}$. in width (dry specimen, Willapa Harbor).

Localities.--Willapa Harbor, Wash., July 15, 1938, on limb washed on shore. Harriet Harbor, Moresby Island, British Columbia, July 29,1934 , on kelp with $L$. pectinata pacifica. William Head, Vancouver Island, British Columbia, 1926, from ship's bottom. Friday Harbor, Wash., July 14, 1937, on floating board with L. pectinata pacifica. Lousonne Harbor, Queen Charlotte Island, British Columbia, February 11, 1935, on floating bottle. Aleutian Islands, 1936. 
LePas PECtinata PACIFiCA, new subspecies

Figures 2, 3

Holotype.-U.S.N.M. No. 78233, from Harriet Harbor, British Columbia.

Diagnosis.-Valves brittle and radially striate. No internal umbonal teeth. Ridge from umbo to apex of scutum close to occludent margin. Occludent margin of tergum single. Tergum notched to receive apex of scutum. One short blunt filamentary appendage on each side. No caudal appendages.

Description.-The capitulum is rather thick basally. The plates are white and the surface shows fine radial striations. The growth ridges
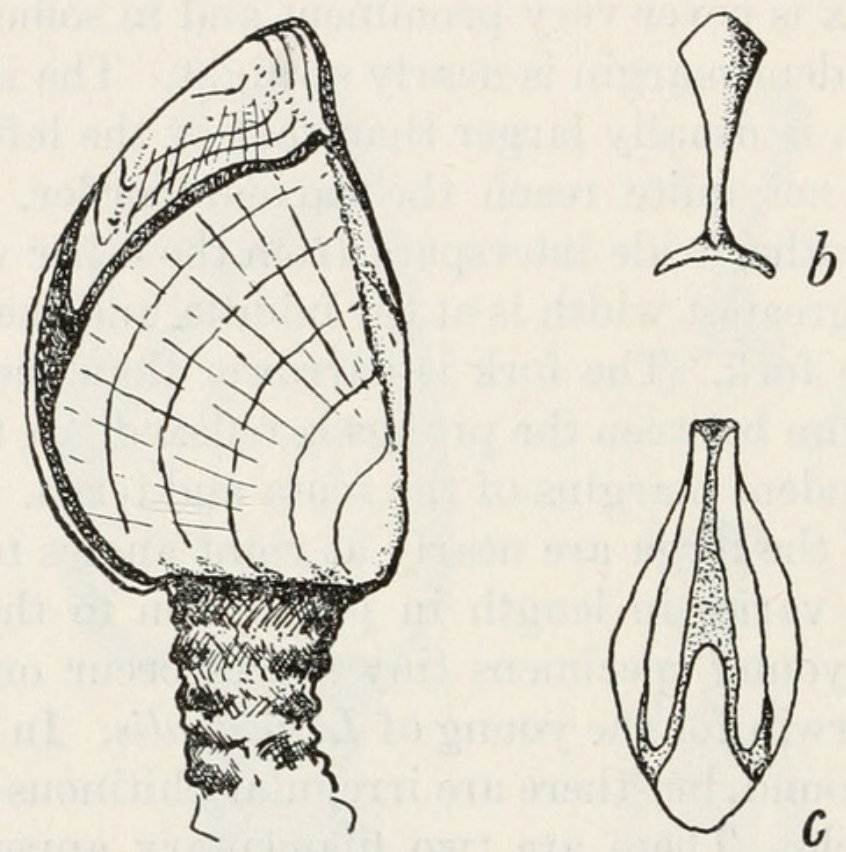

$a$

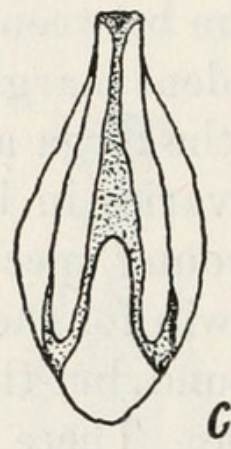

FigURe 2.-Lepas pectinata pacifica, new subspecies, from Harriet Harbor, British Columbia: $a$, Side view, $\times 2 ; b$, carina, external view, $\times 3 ; c$, apex of capitulum from above, $\times 3$.

are more or less prominent and uneven, particularly on the tergum. The plates are very thin and brittle but the edges are not sinuous.

The scuta are subtriangular, with the apex somewhat pointed. Toward the base they are concave internally. The occludent margin is straight, and the ridge from the umbo to the apex is prominent and never more than $1.5 \mathrm{~mm}$. from the occludent margin. The basal margin is not straight but projects downward at the umbo. There is a slight internal basal rim and in most a thickening externally on the basal margin. There are no internal umbonal teeth.

The tergum is triangular and has a notch, usually very conspicuous, on the scutal margin very close to the occludent margin. The occludent margin of the tergum (fig. $2, c$ ) differs from that of the typical form in that it is restricted to a single side of the tergum instead of 
to two sides (compare with fig. $1, c$ ). In this respect $L$. pectinata pacifica resembles $L$. fascicularis.

The carina extends about halfway between the terga. It is rounded at the apex and is approximately the same width until just above the fork, where it is slightly narrower. The fork is a little wider than the carina, and the prongs, which are thin and pointed, diverge at an angle of approximately $180^{\circ}$ as in the typical form. The rim between

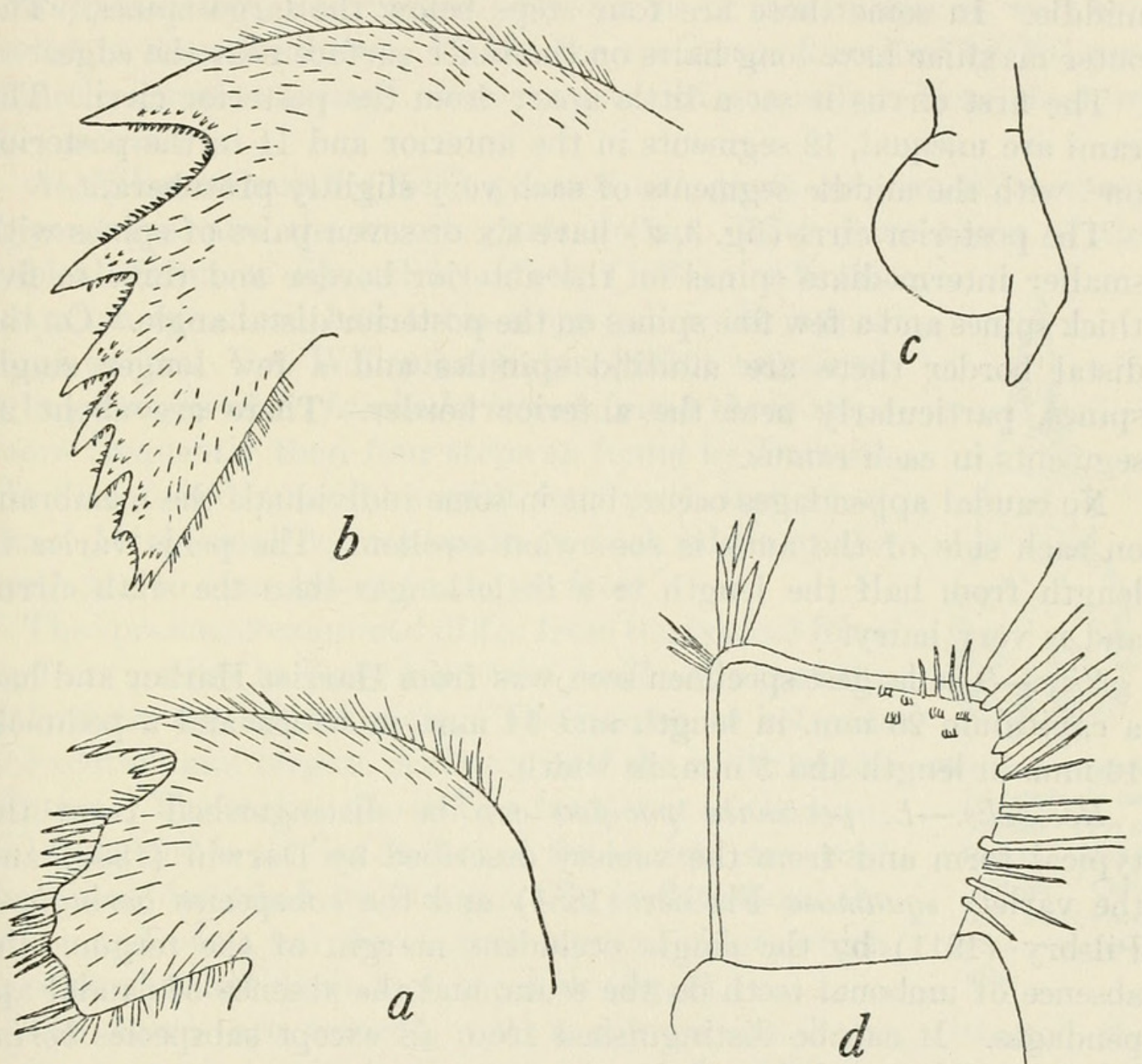

Figure 3.-Lepas pectinata: $a$, Maxilla, $\times 31 ; b$, mandible, $\times 31 ; c$, filamentary appendage, $\times 64 ; d$, middle segment of cirrus VI, $\times 7$.

the prongs is not reflexed. The fork is not deeply embedded in the membrane.

The peduncle varies in length and unlike the typical form is often longer than the capitulum. It is smooth, and no spines occur on the peduncle of young individuals.

One filamentary appendage occurs posteriorly at the base of each first cirrus (fig. 3,c). They do not develop until the capitulum is about $7 \mathrm{~mm}$. in length and at first are extremely small. In larger individuals they are short and thick with a blunt end.

The mouth parts, particularly the maxillae and mandibles (figs. $3, a, b)$, are variable as in the typical form. The palpi are narrow at 
the ends and swollen at the point of attachment to the labrum. The mandibles have five or six teeth and the inferior angle, which is bordered by several long spines, may be either single or divided into two points. The surface is hairy, and small spines occur on both edges of the teeth as well as on the surface. The maxillae have two or three large unequal spines, usually followed by three steps with the lower one wider and frequently showing a small notch in the middle. In some there are four steps below the large spines. The outer maxillae have long hairs on the inner surface near the edge.

The first cirrus is set a little apart from the posterior cirri. The rami are unequal, 12 segments in the anterior and 11 in the posterior one, with the middle segments of each very slightly protuberant.

The posterior cirri (fig. $3, d$ ) have six or seven pairs of spines with smaller intermediate spines on the anterior border and three to five thick spines and a few fine spines on the posterior distal angle. On the distal border there are multifid spinules and a few longer single spines, particularly near the anterior border. There are about 25 segments in each ramus.

No caudal appendages occur, but in some individuals the membrane on each side of the anus is somewhat swollen. The penis varies in length from half the length to a little longer than the sixth cirrus and is very hairy.

Size.-The largest specimen seen was from Harriet Harbor and had a capitulum $20 \mathrm{~mm}$. in length and $14 \mathrm{~mm}$. in width and a peduncle $16 \mathrm{~mm}$. in length and $5 \mathrm{~mm}$. in width.

Remarks.-L. pectinata pacifica can be distinguished from the typical form and from the variety described by Darwin (1851) and the variety squamosa Fischer (1884) and the subspecies beringiana Pilsbry (1911) by the single occludent margin of the tergum, the absence of umbonal teeth on the scuta, and the absence of caudal appendages. It can be distinguished from all except subspecies beringiana by the smoothness of the plates.

Localities.-Biorka Island, Alaska, July 21, 1936, on L. fascicularis. Queen Charlotte Sound, British Columbia, July 6, 1934, on L. fascicularis. Lousonne Harbor, Queen Charlotte Island, British Columbia, February 11, 1935, with L. anatifera. Harriet Harbor, Moresby Island, British Columbia, August 29, 1934, on kelp with L. anatifera. Naden Harbor, Graham Island, British Columbia, August 28, 1937, on kelp. Swiftsure Bank (lat. $48^{\circ} 31^{\prime}$ N., long. $124^{\circ} 53^{\prime}$ W.), July 10, 1935, on Fucus; August 5, 1934, on L. fascicularis. Friday Harbor, Wash., July 13, 1937, on floating limb; July 14, 1937, on floating board, with $L$. anatifera; July 26, 1937, on floating board. Willapa Harbor, 1922, on kelp. Manzanita Beach, Oreg., August 20, 1938, on driftwood, washed on shore. Short Sandy Beach, Oreg., August 20, 1938, on Fucus, washed on shore. 


\section{LEPAS FASCICULARIS AURIVILLII Nilsson-Cantell}

\section{Figure 4}

Lepas fascicularis aurivillii Nilsson-Canteli, 1921, p. 238.

Diagnosis.-Externally like the typical form. Cirri shorter, with broader segments, covered with fine hairs. Carina same width as in the typical form (Nilsson-Cantell).

Supplementary description.-Specimens of this subspecies were collected in three localities. Unlike the specimens described by NilssonCantell, certain external characters varied somewhat from those of L. fascicularis.

As Nilsson-Cantell (1921) pointed out, there are five filamentary appendages, and the mouth parts do not differ from those of the typical form, as figured by Hoek (1883). All the maxillae examined had three steps below the upper large spines. Von Willemöes-Suhm (1876) examined a large series of $L$. fascicularis and found three steps more frequently than four steps as found by Darwin. He also found mandibles with four teeth instead of five. Many small spines occur on both edges of the teeth and to some extent on the surface.

The specimens examined differ from the typical form and are similar to Darwin's variety villosa in that the valves are not approximate. The interspace between the scutum and tergum is almost half the width of the scutum. The carina also differs from that of the typical form and is similar to that of the variety donovani Leach as described by Darwin. It is flat above the umbo and has a narrow central external ridge, which is somewhat less distinct on the disk (fig. 4).

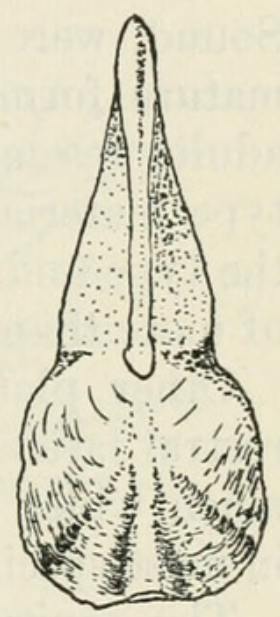

Figure 4.-Lepas fascicularis aurivillii f rom Biorka Island, Alaska : Carina, external view. Natural size.

The valves are covered with a spinose membrane, although the spines are more minute than those seen by Darwin. Hoek (1883) also found the smaller spines on $L$. fascicularis from the Pacific.

Size.-The largest specimen had a capitulum $47 \mathrm{~mm}$. in length and $37 \mathrm{~mm}$. in width; the peduncle was $10 \mathrm{~mm}$. in length and $8 \mathrm{~mm}$. in width. The largest specimen described by Nilsson-Cantell (1921) had a capitulum $8 \mathrm{~mm}$. in length and $6 \mathrm{~mm}$. in width.

Localities.-Bangkok, on Limulus; Java Sea (Nilsson-Cantell). New records: Queen Charlotte Sound, British Columbia, July 6, 1934, floating, a number of specimens attached to gelatinous balls. Biorka Island, Alaska, July 21, 1926, also attached to gelatinous balls. Swiftsure Bank (lat. $48^{\circ} 31^{\prime}$ N., long. $124^{\circ} 53^{\prime}$ W.), August 5, 1934, attached to a gelatinous ball. 


\section{Genus SCALPELLUM Leach}

\section{SCALPELLUM COLUMBIANUM Pilsbry}

FiguRe 5

Scalpellum (Arcoscalpellum) columbianum PilsBrx, 1909, p. 367 ; CoRnwalL, 1930 , pp. 215-217.

This species was described by Pilsbry from three specimens from British Columbia. Cornwall (1930) described the mouth parts of two specimens also from British Columbia and pointed out several variations from the type material, i. e., the greater width of the inframedian latus, the presence of hair on the outer margin of the carina, and the slightly greater width of the capitulum. Cornwall also figures three small individuals found with the two adults.

Five adult specimens of this species, found off Allen Bank, Puget Sound, were unfortunately preserved dry. One adult and two immature forms were found off Point No Point, Puget Sound. The adults resembled those figured by Cornwall more nearly than the type material. In all, the inframedian latus is wider than that of the type and the capitulum is only 1.8 times as long as wide instead of more than twice as long as in the type.

Other plates show some variation in proportion. In most the rostral latus was more nearly the same width throughout instead of much wider near the inframedian latus. Also the upper latus was in most specimens wider in proportion to the length than in the type.

The capitulum is covered with a thin membrane on which fine spines occur. These are slightly longer and more numerous near the carina and are especially long along the ridges of the carina. In all the specimens the scales on the peduncle are more numerous, 25 to 30 in a row, instead of about 10 as in the type.

The younger of the two immature forms (fig. 5, a) was very similar to the immature form of S. gruvelianum figured by Broch (1922). All the plates except the rostral latus and rostrum were present. The surface was covered with a membrane with fine hairs and a pair of "tentacular appendages" covered with fine hairs occurred at the apex of the capitulum. At the base of the capitulum there were two large scales on each side and one smaller scale below the rostral angles of the scuta. In the older specimen the rostral latus was present, and a sixth scale occurred on the peduncle below the carina. In neither individual could the rostrum be distinguished.

The mouth parts of the specimen examined differed somewhat from Cornwall's description. The upper part of the labrum is bullate (fig. 5, b), and the palpi are somewhat acuminated. The fourth tooth of the mandible is less blunt, and a greater part of the surface is covered with hairs (fig. 5, f). The maxilla (fig. 5, $d$ ) shows no notch 
below the upper large pair of spines. There are seven pairs of spines below the upper pair. The last three are on a slight prominence. The inferior border and the surface near the origin of the spines are covered with fine hairs. Highly prominent tubular olfactory organs are situated on the external surface of the outer maxillae.
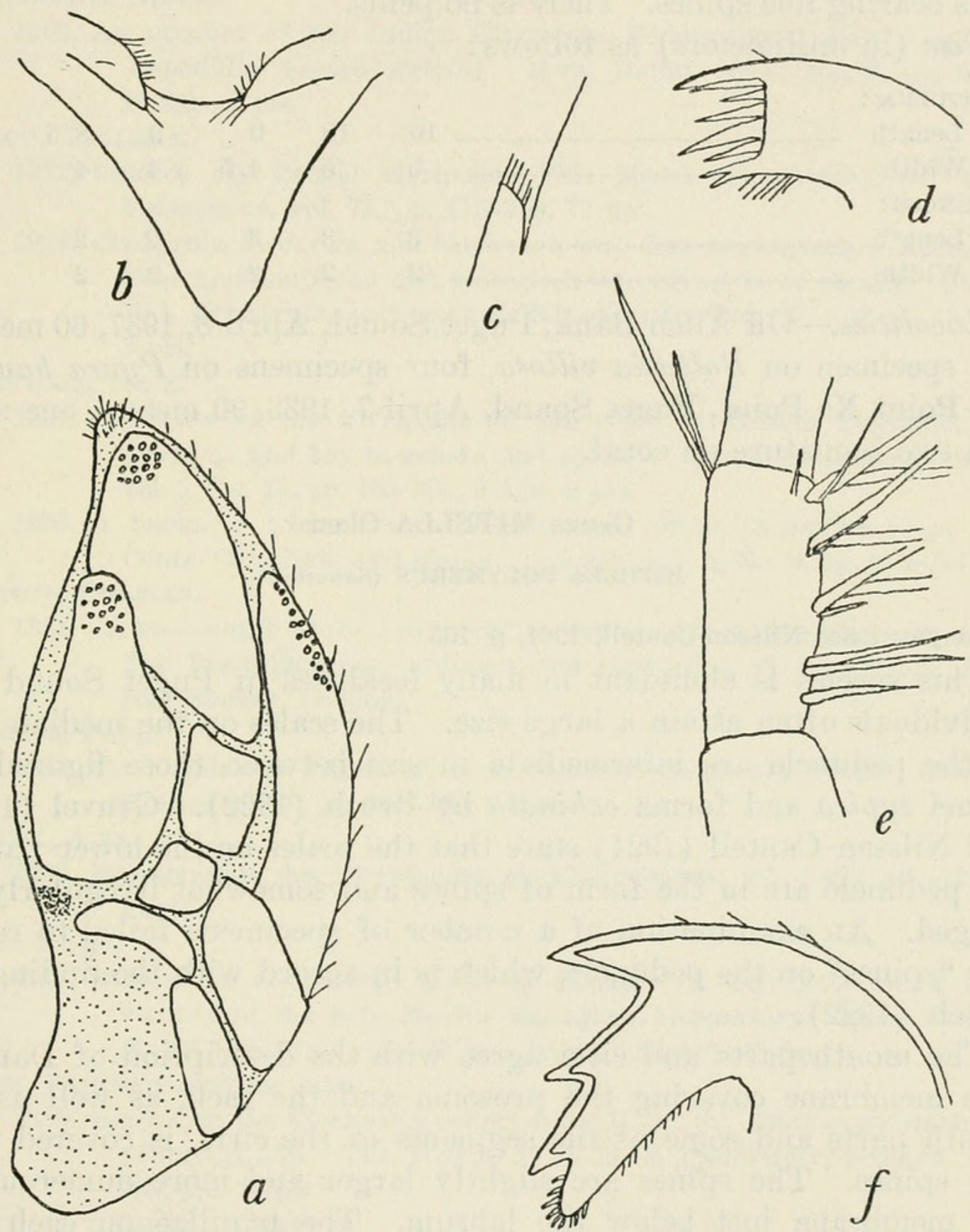

Figure 5.- Scalpellum columbianum from Point No Point, Puget Sound : $a$, Immature, side view, $\times 58 ; b$, labrum, $\times 39$; , caudal appendage, $\times 39 ; d$, maxilla, $\times 80 ; e$, sixth segment of cirrus VI, $\times 80 ; f$, mandible, $\times 80$.

The anterior ramus of cirrus $I$ is only slightly shorter than the posterior ramus; both rami have seven segments. The first cirrus is set a little apart from the other cirri. The second cirrus is longer than the first and a little shorter than the third. The rami of both the second and third cirri are unequal in length. The posterior cirri are slightly curled. The sixth cirrus (fig. 5,e) has four pairs of 
spines on the median segments of the outer ramus and five pairs on the median segments of the inner. There are two long thin spines on the posterior distal angle and usually one very fine short spine on the anterior distal border.

The caudal appendages (fig. 5, c) are short and flat with truncated ends bearing fine spines. There is no penis.

Size (in millimeters) as follows:

\section{Capitulum :}

Length

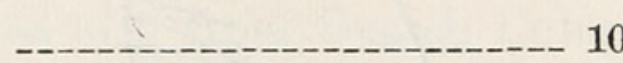

Width

Peduncle:

Length $10 \quad 10$

Width

$\begin{array}{lllll}3 & 3 & 3 & 2 & 2\end{array}$

8.5

$\begin{array}{llll}5 & 4.5 & 4 & 4\end{array}$

Localities.-Off Allen Bank, Puget Sound, April 8, 1937, 60 meters; one specimen on Boltenia villosa, four specimens on Pyura haustor. Off Point No Point, Puget Sound, April 7, 1933, 90 meters, one adult and two immature on coral.

\section{Genus MITELLA Oken \\ MITELLA POLYMERUS (Sowerby)}

Synonymy: See Nilsson-Cantell, 1921, p. 165.

This species is abundant in many localities in Puget Sound and individuals often attain a large size. The scales on the median part of the peduncle are intermediate in size between those figured for forma typica and forma echinata by Broch (1922). Gruvel (1905) and Nilsson-Cantell (1921) state that the scales on the lower part of the peduncle are in the form of spines and somewhat irregularly arranged. An examination of a number of specimens failed to reveal any "spines" on the peduncle, which is in accord with the findings of Broch (1922).

The mouth parts and cirri agree with the description of Darwin. The membrane covering the prosoma and the sack, as well as the mouth parts and some of the segments of the cirri, is covered with fine spines. The spines are slightly larger and more numerous on the membrane just below the labrum. The papillae on each side of the filamentary appendages and on the sack have short spines and spinules similar to those found on the filamentary appendages.

In many of the large specimens the caudal appendages have two segments, with short spines at the upper edge of each. In two specimens only one caudal appendage occurred.

Localities.-Washington: False Bay, San Juan Island; Iceberg Point, Lopez Island; Goose Island; Seal Rock and Waadah Island, Neah Bay. Bandon, Oreg. Trinidad, Calif. Ensenada, Lower California. 


\section{LITERATURE CITED}

Annandale, Nelson.

1909. An account of the Indian Cirripedia Pedunculata. Part I.-Family Lepadidae (sensu stricto). Mem. Indian Mus., vol. 2, pp. 61-137, 11 figs., 2 pls.

Broch, HJalmar.

1922. Studies on Pacific cirripeds. Vid. Medd. Dansk Naturh. Foren. K $\varnothing$ benhavn, vol. 73, pp. 215-358, 77 figs.

1924. Cirripedia thoracica von Norwegen und dem norwegischen Nordmeere. Eine systematische und biologisch-tiergegraphische Studie. Skrifter Vid. Kristiania, mat.-naturv. Klasse, 1924, No. 17, 121 pp., 35 figs., 3 pls.

Cornwall, Ira E.

1925. A review of the Cirripedia of the coast of British Columbia, with glossary, and key to genera and species. Contr. Can. Biol., new ser., vol. 2, No. 18, pp. 469-502, 9 figs., 6 pls.

1930. A barnacle (Scalpellum columbianum) from Departure Bay, B. C. Contr. Can. Biol. and Fisher., new ser., vol. 5, No. 9, pp. 215-217, 1 fig.

Darwin, Charles.

1851. A monograph of the sub-class Cirripedia, with figures of all the species. The Lepadidae; or, pedunculated cirripedes, xi +400 pp., 10 pls. Ray Society, London.

\section{Fischer, Paul.}

1884. Cirrhipèdes de l'Archipel de la Nouvelle Calédonie. Bull. Soc. Zool. France, vol. 9, pp. 355-360, 1 fig.

Gruver, Abei.

1905. Monographie des Cirrhipèdes ou Thécostracés, xii +472 pp., 427 figs. Paris.

Hrio, Fujio.

1937. Studies on cirripedian fauna of Japan. II. Cirripeds found in the vicinity of the Seto Marine Biological Laboratory. Mem. Coll. Sci. Kyoto Imp. Univ., ser. B, vol. 12, pp. 385-478, 43 figs.

Hoek, Paulus Peronius Cato.

1883. Report on the Cirripedia collected by H. M. S. Challenger during the years 1873-76. The Voyage of H. M. S. Challenger, Zoology, vol. 8, $169, \mathrm{pp} ., 13 \mathrm{pls}$.

Miranda y Rivera, Alvaro de.

1921. Algunos crustacéos de la colección del Laboratorio Biologico de Málaga. Bol. Pescas, Madrid, vol. 6, pp. 179-205, 3 figs.

Nilsson-Canteli, Carl August.

1921. Cirripeden-Studien. Zur Kenntnis der Biologie, Anatomie und Systematik dieser Gruppe. Zool. Bidrag Uppsala, vol. 7, pp. 75-395, 89 figs., 3 pls.

1928. Studies on cirripeds in the British Museum (Nat. Hist.). Ann. Mag. Nat. Hist., ser. 10, vol. 2, pp. 1-39, 16 figs.

1921. Cirripeds from the Juan Fernandez Islands, in "The Natural History of Juan Fernandez and Easter Islands," edited by Dr. Carl Skottsberg, Zoology, vol. 3, pt. 4, pp. 483-492, 3 figs. 
Pilsbry, Henry Augustus.

1907. The barnacles (Cirripedia) contained in the collections of the U. S. National Museum. U. S. Nat. Mus. Bull. 60, 122 pp., 36 figs., 11 pls. 1909. A new species of Scalpellum from British Columbia. Proc. Acad. Nat. Sci. Philadelphia, vol. 61, pp. 367-368, 2 figs.

1911. Barnacles of Japan and Bering Sea. Bull. U. S. Bur. Fisheries, vol. 29 (1909), pp. 59-84, 11 figs., 10 pls.

WeLtNer, WiLhelm.

1900. Die Cirripedien der Arktis, in Römer and Schaudinn's "Fauna Arctica," vol. 1, pp. 287-312, 1 fig., 1 pl.

WILLEMÖES-SUHM, RUdOLF voN.

1876. On the development of Lepas fascicularis and the "Archizoëa" of Cirripedia. Philos. Trans. Roy. Soc. London, vol. 166, pp. 131-154, 6 pls. 


\section{$2 \mathrm{BHL}$ Biodiversity Heritage Library}

Henry, Dorapriaulx. 1940. "Notes on some pedunculate barnacles from the North Pacific." Proceedings of the United States National Museum 88(3081), 225-236. https://doi.org/10.5479/si.00963801.88-3081.225.

View This Item Online: https://www.biodiversitylibrary.org/item/32771

DOI: https://doi.org/10.5479/si.00963801.88-3081.225

Permalink: https://www.biodiversitylibrary.org/partpdf/33549

\section{Holding Institution}

Smithsonian Libraries

\section{Sponsored by}

Smithsonian

\section{Copyright \& Reuse}

Copyright Status: NOT_IN_COPYRIGHT

Rights: https://www.biodiversitylibrary.org/permissions/

This document was created from content at the Biodiversity Heritage Library, the world's largest open access digital library for biodiversity literature and archives. Visit BHL at https://www.biodiversitylibrary.org. 